DOI: $10.1515 /$ pts-2017-0003

\title{
DESIGN OF LOW-TORQUE-RIPPLE SYNCHRONOUS RELUCTANCE MOTOR WITH EXTERNAL ROTOR
}

\author{
L. Lavrinovicha, J. Dirba, R. Dobriyan \\ Riga Technical University, \\ 12/1 Azenes Str., Riga, LV-1048, LATVIA \\ e-mail: janis.dirba@rtu.lv
}

\begin{abstract}
The paper presents new designs for synchronous reluctance motors that have external rotor (segment-shaped rotor, rotor with additional non-magnetic space to the quadrature axis of the rotor, and rotor with several flux barriers). Impact of the external rotor configuration on the electromagnetic torque and torque ripple is analysed. Electromagnetic torque ripple factor is calculated for each studied motor using the results of magnetic field numerical calculations.
\end{abstract}

Keywords: external rotor motor, reluctance motor, torque ripple, torque ripple factor.

\section{INTRODUCTION}

After intensive import of vector control drive, synchronous reluctance motors have received great attention as a good alternative to other types of motors, such as brushed motors or induction motors. Consequently, there is renewed interest in the design of synchronous reluctance motor in order to obtain results that are comparable with other widely used motors.

Many recent studies [1]-[6] present a variety of new designs of synchronous reluctance motors and techniques for improving the existing motor designs. Most studies are devoted to the determination and justification of the rational design of reluctance motor with high electromagnetic torque, where the goal is achieved by solving such a problem as a reduction of the magnetic flux in the quadrature axis (qaxis) and an increase in the direct axis (d-axis). For example, results obtained in paper [1] show that direct magnetic flux should be increased, but quadrature magnetic flux should be reduced. The fact that one of the ways to increase the electromagnetic torque is the simultaneous execution of synchronous reluctance motor as a two-pole motor $(2 \mathrm{p}=2)$ is also presented in paper [1].

In many cases, increasing the electromagnetic torque by increasing difference of magnetic fluxes in the direct and quadrature axes causes a problem of emergence of high torque ripple due to uneven air gap in the motor.

Papers [4]-[5] present the study of difference methods for reducing torque ripple, which in some cases does not have effective results. In order to find the 
effective solution to suppress the electromagnetic torque ripple and at the same time to maintain the average value of the electromagnetic torque, it is necessary to carry out a deep analysis of the distribution of the magnetic field in the active part of the studied machine depending on the configurations of ferromagnetic and non-magnetic parts of the rotor.

The goal of the research is to show a general approach to the design of external rotor synchronous reluctance motor and reduction of electromagnetic torque ripple in such motors.

\section{ANALYSIS OF ROTOR DESIGNS FOR SYNCHRONOUS RELUCTANCE MOTOR}

Published patent [2] describes the developed designs for synchronous reluctance motor with the external rotor, where the rotor is made up of mutually magnetically isolated laminated packages of electrical steel (see Fig. 1). The rotor packages have narrow sides of segmental shape, each with its active surface directed to the stator and separated from it by an air gap. Pole coverage factor for such a motor is increased to 0.95-0.98, which increases specific electromagnetic torque in comparison with a motor with salient poles.

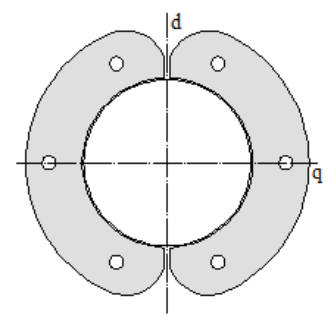

Fig. 1. A cross-section illustration of segment-shaped external rotor for a synchronous reluctance motor.

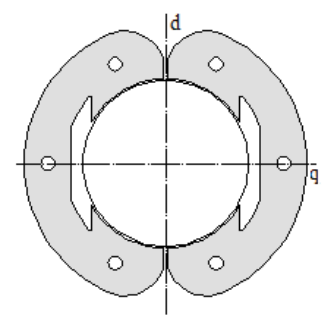

Fig. 2. A cross-section of segment-shaped external rotor with non-magnetic spaces along quadrature axis for a synchronous reluctance motor.

Results presented in paper [4] show that synchronous reluctance motor with a segment-shaped external rotor has significant electromagnetic torque ripple. In addition, the known method of torque ripple reduction - skewed rotor packages by value of the stator slot pitch in such a motor can significantly reduce torque ripple; however, in such a case the average value of electromagnetic torque greatly decreases. Furthermore, in this case, copper losses will be greater, and automatic creation of winding will be quite complicated due to longer stator winding. 
In order to increase electromagnetic torque of segment-shaped synchronous reluctance motor, studies [6]-[7] propose making an additional non-magnetic space in each segment of the rotor (see Fig. 2). In this case, the non-magnetic spaces are created in the direction of quadrature axis of the motor, which reduce quadrature magnetic flux. As a result, electromagnetic torque increases. In addition, non-magnetic spacing in the rotor segments reduces weight and, thus, increases motor specific torque.

Results published in paper [7] show that torque ripple in the synchronous reluctance motor is strongly influenced by a number of stator slots and width of slot opening. According to the results obtained in paper [7], it has been concluded that after increasing the number of stator slots, torque ripple is substantially reduced, while an amplitude value of the fundamental harmonic of electromagnetic torque is slightly increased. Thus, increasing the number of stator slots from $Z=6$ to $Z=$ 18 leads to an approximately twofold decrease in the torque ripple factor and to an increase in the amplitude value of fundamental harmonic of electromagnetic torque by $5 \%$.

Research results for a synchronous reluctance motor with an inner rotor presented in papers [5] and [8] show that the effective difference between the direct and quadrature magnetic fluxes can be achieved using the rotor design with several nonmagnetic flux barriers (see Fig. 3).

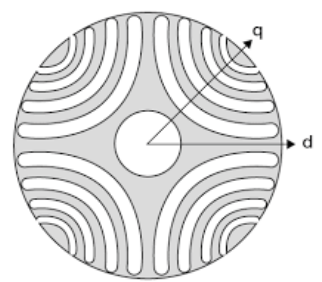

Fig. 3. A cross-sectional illustration of an inner rotor with flux barriers for a synchronous reluctance motor.

The analysis of design characteristics of the inner rotor of reluctance motor, which is presented in Fig. 3, requires studying torque ripple reduction opportunities by creating the external rotor of reluctance motor with several non-magnetic flux barriers (see Fig. 4 a). In order to increase mechanical strength, rotor flux barriers are designed with fasteners as shown in Fig. 4 b. The width of the flux barriers is equal to that of stator slot opening, and thickness of fasteners is $4 \mathrm{~mm}$.

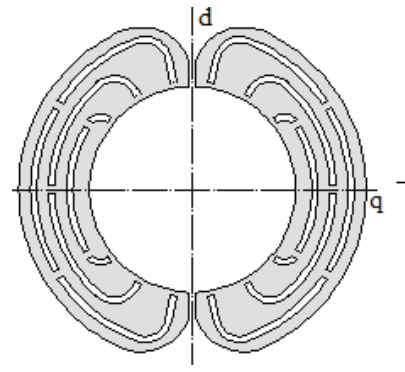

(a)

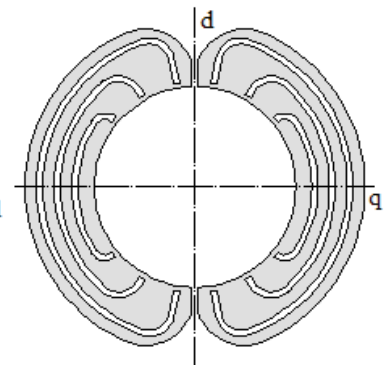

(b)

Fig. 4. Cross-sectional illustrations of external rotor with flux barriers for a synchronous reluctance motor. 


\section{ELECTROMAGNETIC TORQUE AND TORQUE RIPPLE FACTOR}

As it is known [9] from equation (1), electromagnetic torque of synchronous motor with an unsaturated magnetic circuit depending on the angle $\varepsilon$ between the rotor direct axis and axis of armature magnetizing force has sinusoidal changing.

$$
T_{e m}=\frac{1}{2} m p L_{a d} I_{1}^{2}\left(1-\frac{k_{q}}{k_{d}}\right) \sin (2 \varepsilon),
$$

$$
\begin{array}{ll}
\text { where } m & \text { is the number of phases; } \\
p & \text { is the number of pole pairs; } \\
L_{a d} & \text { is the inductance corresponding to the armature magnetic flux along } \\
\text { the direct axis; } & \\
I_{1} & \text { is the armature current; } \\
k_{q} / k_{d} & \begin{array}{l}
\text { is the armature reaction factors along the direct and quadrature } \\
\text { axis ratio. }
\end{array}
\end{array}
$$

That is why it is appropriate to distribute the fundamental harmonic $T_{1 e m}$ of the motor electromagnetic torque curve, which has a sinusoidal shape. In turn, torque ripple can be evaluated by comparing the calculated electromagnetic torque curve with the fundamental harmonic. For this purpose, the torque ripple factor (2) is derived:

$$
k_{p}=\frac{\sum_{i=1}^{n}|\Delta a|}{n \cdot T_{\max 1}},
$$

where $n \quad$ is the number of evenly selected points on the half interval of the electromagnetic torque sinusoidal curve;

$\Delta a \quad$ is the difference between values of the electromagnetic torque $T_{e m}$ and the fundamental harmonic of electromagnetic torque $T_{e m 1}$ in relevant points;

$T_{\max 1}$ is the maximum of electromagnetic torque fundamental harmonic.

\section{SIMULATION OF MAGNETIC FIELD OF THE STUDIED MOTOR AND RESULT ANALYSIS}

In order to assess the possibilities to reduce torque ripple in a synchronous reluctance motor at the same time ensuring high torque, the motor with different rotor designs is investigated with the help of magnetic field simulation by a finite element method. In this case, the electromagnetic torque of the motor is calculated using the Maxwell stress tensor method that is described in [10]. Using the Maxwell stress tensor, electromagnetic torque is described by surface integral (3) of the surface in the middle of motor air gap: 


$$
T_{e m}=\oint_{S}\left(\bar{r} \times\left[\frac{1}{2 \mu_{0}}\left(B_{n}^{2}-B_{t}^{2}\right) \times \bar{n}-\frac{1}{\mu_{0}} B_{n} B_{t} \bar{t}\right]\right) d S,
$$

where $T_{e m}$ is the electromagnetic torque;

$\mu_{0}$ is vacuum magnetic permeability;

$\bar{n}$ is the normal vector of the point on a closed surface $S$;

$\bar{r}$ is the radius-vector of the point on a closed surface $S$;

$\bar{t}$ is the tangent vector of the point on a closed surface $S$;

$B_{n}$ is the normal component of the magnetic flux density;

$B_{t}$ is the tangential component of the magnetic flux density.

The accuracy of the electromagnetic torque calculation by the Maxwell tensor depends essentially on the spatial position of integrating contour, degree and evenness of the mesh in the computational domain. In order to eliminate the influence of these factors on the calculation results, the contour of integration is offered to put in the so-called box, as shown in Fig. 4.
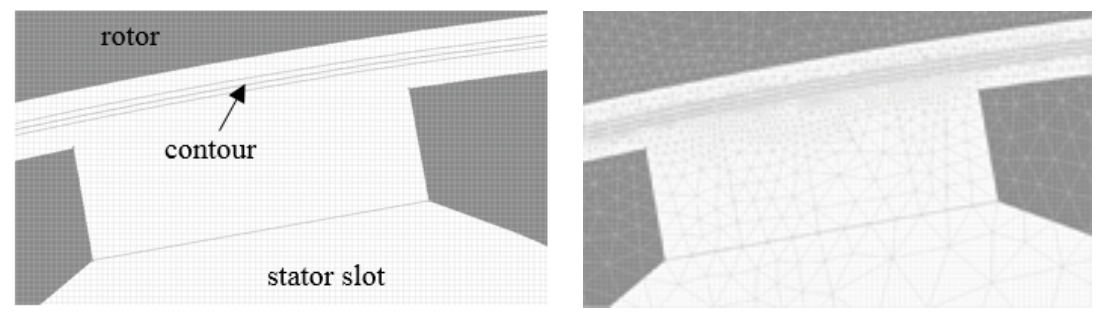

Fig. 4. Illustration of integration contour in the rotor air gap.

The following sizes of the motor under analysis are taken as constant: the outer diameter is $170 \mathrm{~mm}$, the axial length of the motor active part is $100 \mathrm{~mm}$, the anchor outer diameter is $100 \mathrm{~mm}$ and air gap is $0.5 \mathrm{~mm}$. The results presented in [7] show that the effective number of stator slots for the motor with the accepted dimensions is $Z=18$. Larger slot number is no desirable from the perspective of dental mechanical strength and winding creation.

Figures 5 and 6 present the magnetic flux distribution and the electromagnetic torque curves for the studied motor with different rotor designs. The calculated torque ripple factor for the studied motor with different rotor designs is presented in Table 1. Figures 5 and 6 demonstrate results for the following synchronous reluctance motor designs: (a) - the motor with a segment-shaped external rotor; (b) - the motor with a segment-shaped external rotor having non-magnetic space in quadrature axis; (c) - the motor with a segment-shaped external rotor with three nonmagnetic flux barriers; (d) - the motor with a segment-shaped external rotor with three non-magnetic flux barriers and mechanical fasteners in barriers. Slot number of the stator is selected as $Z=18$. 


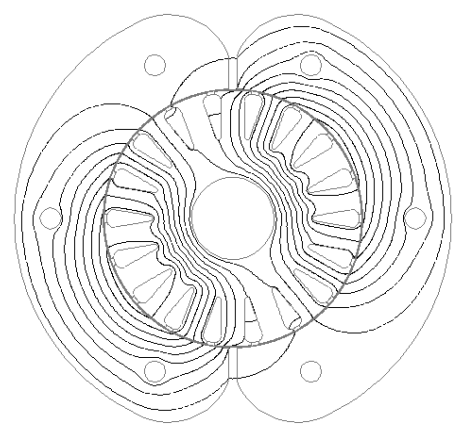

(a)

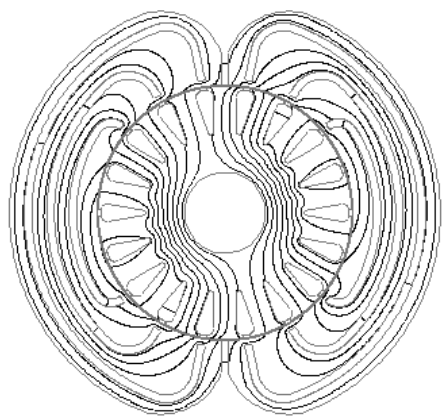

(c)

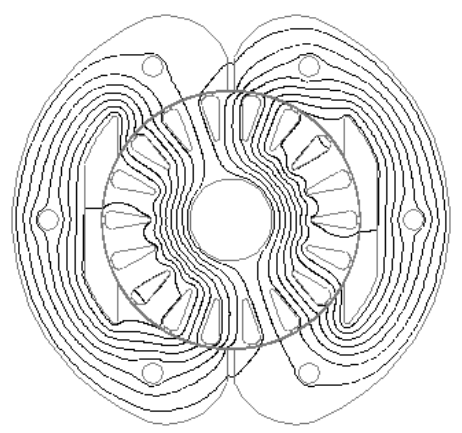

(b)

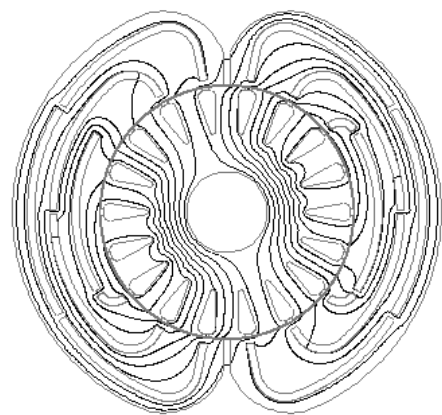

(d)

Fig. 5. Magnetic field distribution of the studied motor at $\varepsilon=30 \mathrm{deg}$.

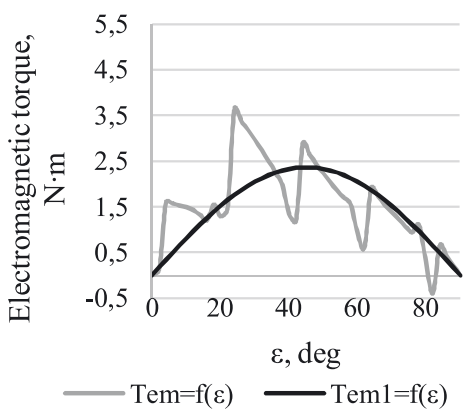

(a)

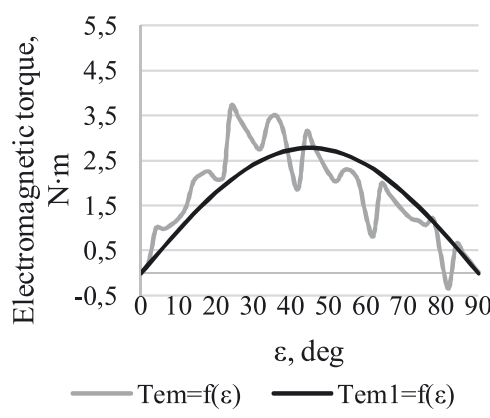

(c)

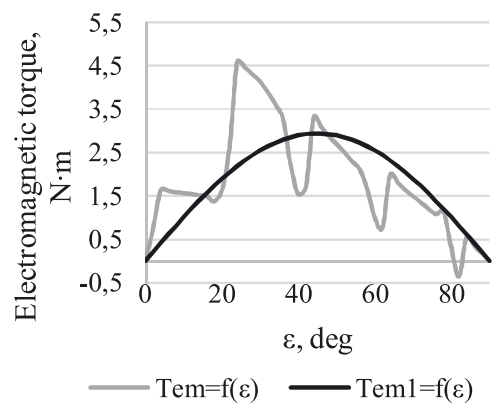

(b)

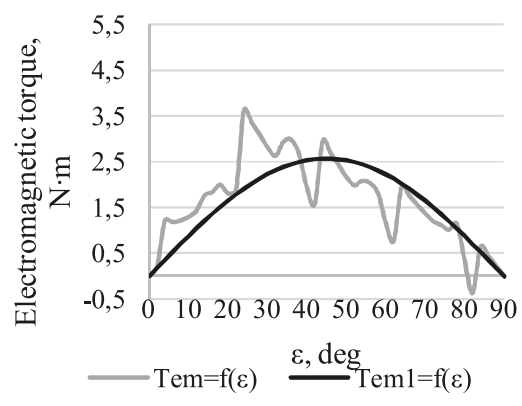

(d)

Fig. 6. Electromagnetic torque curves for the studied motor with different rotor designs. 
Calculated Results for the Studied Motor with Different Rotor Designs

\begin{tabular}{|l|c|c|c|c|}
\hline & Design $(a)$ & Design $(b)$ & Design $(c)$ & Design $(d)$ \\
\hline Torque ripple factor, $k_{p}$ & 0.204 & 0.227 & 0.174 & 0.177 \\
\hline Fundamental harmonic, $T_{\max 1}$ & $2.365 \mathrm{~N} \cdot \mathrm{m}$ & $2.931 \mathrm{~N} \cdot \mathrm{m}$ & $2.776 \mathrm{~N} \cdot \mathrm{m}$ & $2.576 \mathrm{~N} \cdot \mathrm{m}$ \\
\hline
\end{tabular}

From the obtained results (see Table 1) it can be concluded that the highest value of the fundamental harmonic amplitude of electromagnetic torque is demonstrated by the motor with a segment-shaped external rotor having non-magnetic spacing in the quadrature axis. However, the motor with such rotor design has the highest torque ripple coefficient. In order to reduce torque ripple, it is necessary to establish an even air gap as much as possible. For example, the first motor design (design (a)) has a small gap between rotor segments (pole coverage factor is 0.95 ) so that the torque ripple is smaller in comparison with design (b), but since the air gap is uneven due to stator slots, ripple is also significant. However, the motor design (a) has a smaller value of electromagnetic torque fundamental harmonic amplitude. By creating flux barriers in the rotor segments, it reduces quadrature magnetic flux, thereby increasing the electromagnetic torque. As inner surface of this rotor is even and the width of barriers is equal to that of slot opening, torque ripple is smaller.

\section{CONCLUSIONS}

Based on the results obtained in the present research, the following conclusions can be drawn:

1. Comparison of the studied rotor designs for a synchronous reluctance motor shows that the motor with a segment-shaped external rotor with non-magnetic space in the quadrature axis has the highest value of the electromagnetic torque fundamental harmonic amplitude. However, the same value for the motor with an external rotor with flux barriers is less than $5 \%$, and for the motor with an external segment-shaped rotor is less than $19 \%$.

2. The motor with non-magnetic barriers in the rotor has the smallest torque ripple. Torque ripple factor for the motor that has the rotor with non-magnetic space in quadrature axis is higher than $30 \%$.

3. In practice, the creation of the mechanical fastening in the flux barriers of the rotor does not affect the torque ripple, but slightly reduces the fundamental harmonic amplitude of electromagnetic torque.

\section{ACKNOWLEDGEMENTS}

The present research has been supported by the State Research Programme “LATENERGI”. 


\title{
REFERENCES
}

1. Levins, N., Pugachev, V., Dirba, J., \& Lavrinovicha, L. (2013). High-reliability brushless synchronous motors for hand tools and household appliances. Latvian Journal of Physics and Technical Sciences, 50(3), 3-11.DOI:10.2478/lpts-2013-0015

2. Pugachevs, V., Dirba, J., Kukjane (Lavrinovicha) L., Levins, N., \& Orlova, S. (2012). Patent No. LV 14418 B. Riga: Patent Office of the Republic of Latvia (in Latvian).

3. Levins, N., Pugachevs, V., Dirba, J., Lavrinovicha, L., \& Brakanskis, U. (2012). Patent No. LV 14627 B. Riga: Patent Office of the Republic of Latvia (in Latvian).

4. Lavrinovicha, L., Brakanskis, U., \& Dirba, J. (2013). Synchronous reluctance motor without rotor ferromagnetic yoke. In IEEE Eurocon 2013: IEEE Region 8 EuroCon 2013 Conference, 2013, (pp. 1020-1024). Croatia, Zagreb. ISBN 9781467322317.

5. Bomela, X.B., \& Kamper, M.J. (2002). Effect of stator chording and rotor skewing on performance of reluctance synchronous machine. IEEE Transactions on Industry Applications, 38(1), 91-100.

6. Dirba, J., Lavrinovicha, L., \& Dobriyan, R. (2015). Prospects of synchronous reluctance motors usage in low power electrical devices. Latvian Journal of Physics and Technical Sciences, 52(2), 40-48. DOI: 10.1515/lpts-2015-0010

7. Dirba, J., Lavrinovicha, L., \& Dobriyan, R. (2016). Study of the synchronous reluctance motor design. Latvian Journal of Physics and Technical Sciences, 53(4), 22-29. DOI: 10.1515/lpts-2016-0025

8. Matyska, P. (2014). Advantages of synchronous reluctance motors. Transactions on Electrical Engineering, 3(2), 44-47.

9. Lavrinovicha, L., \& Dirba, J. (2015). Brushless Synchronous Motors with External Rotor. Riga: RTU Press (in Latvian).

10. Bianchi, N. (2005). Electrical Machine Analysis Using Finite Elements. USA: CRC Press, Taylor \& Francis.

\section{ĀRĒJĀ ROTORA IZSTRĀDE SINHRONAJAM REAKTİVAJAM DZINĒJAM AR SAMAZINĀTĀM MOMENTA PULSĀCIJĀM}

\author{
J. Dirba, L. Lavrinoviča, R. Dobrijans
}

Kopsavilkums

Aplūkotas jaunākās sinhrono reaktīvo dzinēju konstrukcijas ar ārējo rotoru. Analizēta ārējā rotora izpildījuma (segmentveida rotors, rotors ar papildu gaisa atstarpi pa šḳērsasi un rotors ar vairākām nemagnētiskām barjerām) ietekme uz elektromagnētiskā momenta pulsācijām. Izmantojot magnētiskā laukā aprēḳinus, iegūti momenta pulsāciju skaitliskie rezultāti dažādām ārējā rotora konstrukcijām.

08.09.2016. 